\title{
Species of the Devonian aulacopleurid trilobite Cyphaspides from southeastern Morocco
}

\author{
Brian D.E. Chatterton, ${ }^{1} \odot$ Stacey Gibb, ${ }^{1}$ and Ryan C. McKellar ${ }^{2}$ \\ ${ }^{1}$ Department of Earth and Atmospheric Sciences, University of Alberta, Edmonton, AB T6G 0R2, Canada <brianchatterton@yahoo.com>, \\ <sgibb@ualberta.ca> \\ ${ }^{2}$ Royal Saskatchewan Museum, 2445 Albert Street, Regina, Saskatchewan, S4P 4W7, Canada <ryan.mckellar@gov.sk.ca>
}

\begin{abstract}
Three new species of Cyphaspides are proposed: C. ammari, C. nicoleae, and C. pankowskiorum. These species are based on specimens obtained from Middle Devonian (Eifelian) strata of the Bou Tchrafine Group, near Erfoud, in the Province of Errachidia, southeastern Morocco. The present contribution enhances our knowledge of Cyphaspides by providing details of three new species that are based on well-preserved, complete, and articulated types. The genus Cyphaspides is discussed, and an emended diagnosis is provided. The paleobiogeography, ontogeny, and relationships of the genus are discussed.
\end{abstract}

UUID: http://zoobank.org/4a7aab8f-8c8e-4498-9cc2-6f8c69b85213

\section{Introduction}

Moroccan Lower and Middle Devonian trilobite faunas are known for their abundance and diversity, frequent occurrence of articulated specimens, and exceptional quality of preservation. Numerous papers and monographs have dealt with these trilobites, including some published by the authors of the present work (e.g., Chatterton et al., 2006; McKellar and Chatterton, 2009; Chatterton and Gibb, 2010; Gibb and Chatterton, 2010). Richter and Richter and Gerhard Alberti published much of the earlier work on Moroccan Devonian trilobites (Richter and Richter, 1943; Alberti, 1964, 1966, 1967, 1969, 1970, 1981, 1982, 1983). In one of these works, Alberti (1969, p. 389) identified two pygidia as Cyphaspides ex aff. C. holinensis Růžička, 1939 from the Eifelian (upper Eifelian?) of Hamar Laghdad V (a locality near Erfoud, in southeastern Morocco, close to the RedGreen locality of the present work). He illustrated a pygidium, apparently from the same locality as Cyphaspides sp. (Alberti, 1969, pl. 46, fig. 20). He also mentioned some similar forms from the Rahal schists in the Rabat-Tiflet region of northwestern Morocco (Alberti, 1969, p. 389). Most recently, Crônier et al. (2018) described five partial "more or less eroded" (p. 252) cephala and illustrated one of them (fig. $4 \mathrm{~m}-\mathrm{p}$ ), attributed to Cyphaspides from near the Red-Green locality; however, these specimens were too fragmentary to identify at the species level. We assign Crônier and colleagues' (2018) illustrated specimen with question to Cyphaspides ammari new species. We note that they considered the specimens that they illustrated from Hamar Laghdad to be upper Emsian in age rather than Eifelian.

Cyphaspides was first described from Germany (Roemer, 1855; Novák, 1890; Basse and Lemke, 1996; Lawrence and Stammers, 2014; Basse and Müller, 2016; Helling and Schöllmann, 2018) and has subsequently been found in the Czech
Republic (Barrande, 1846, 1872; Růžička, 1939; Prantl and Přibyl, 1950), the Armorican Massif (Massif Armoricain) of northwestern France (Pillet, 1972), Morocco (Alberti, 1969; Crônier et al., 2018; and herein), China (Yi and Hsiang, 1975; Luo and Jiang, 1985), and Uzbekistan (Kim et al., 1978b).

Specimens of Cyphaspides were collected from three localities in southeastern Morocco: Talawarite, northeast of Erg Chebbi; a small section west of the village of Jorf (west of Erfoud); and the 'Red-Green' locality (located in the area of the Hamar Laghdad mud mound complex, see Fig. 1; Klug et al., 2009). The specimens are assigned to three new species of Cyphaspides. The localities that our specimens of Cyphaspides were obtained from are Eifelian (probably early Eifelian) in age and are located close to the town of Erfoud (see Fig. 1).

Beyond existing reports and our own fieldwork, we have examined pictures posted online of numerous specimens of Cyphaspides from this region of Morocco. Most of these specimens are claimed to have been collected near Jorf, the type locality of two of our species. The pictures of specimens of Cyphaspides posted on the Internet were examined to see how many species appear to be present and to determine whether there are species that are not represented by the specimens available to us and described herein. We concluded that most of the pictures of Moroccan specimens of Cyphaspides posted on the Internet belong to one of the three species that we propose herein. However, at least two of the specimens, purportedly collected from the Jorf locality, may belong to a fourth form. This additional, unnamed form is similar to C. nicoleae new species, and may not be new, but instead a gerontic (large/old) growth stage of that species (see section on C. nicoleae for discussion). Sizes and shapes of numerous specimens will need to be examined before this relationship can be determined, but we have been unable to obtain representative material for coverage herein. 


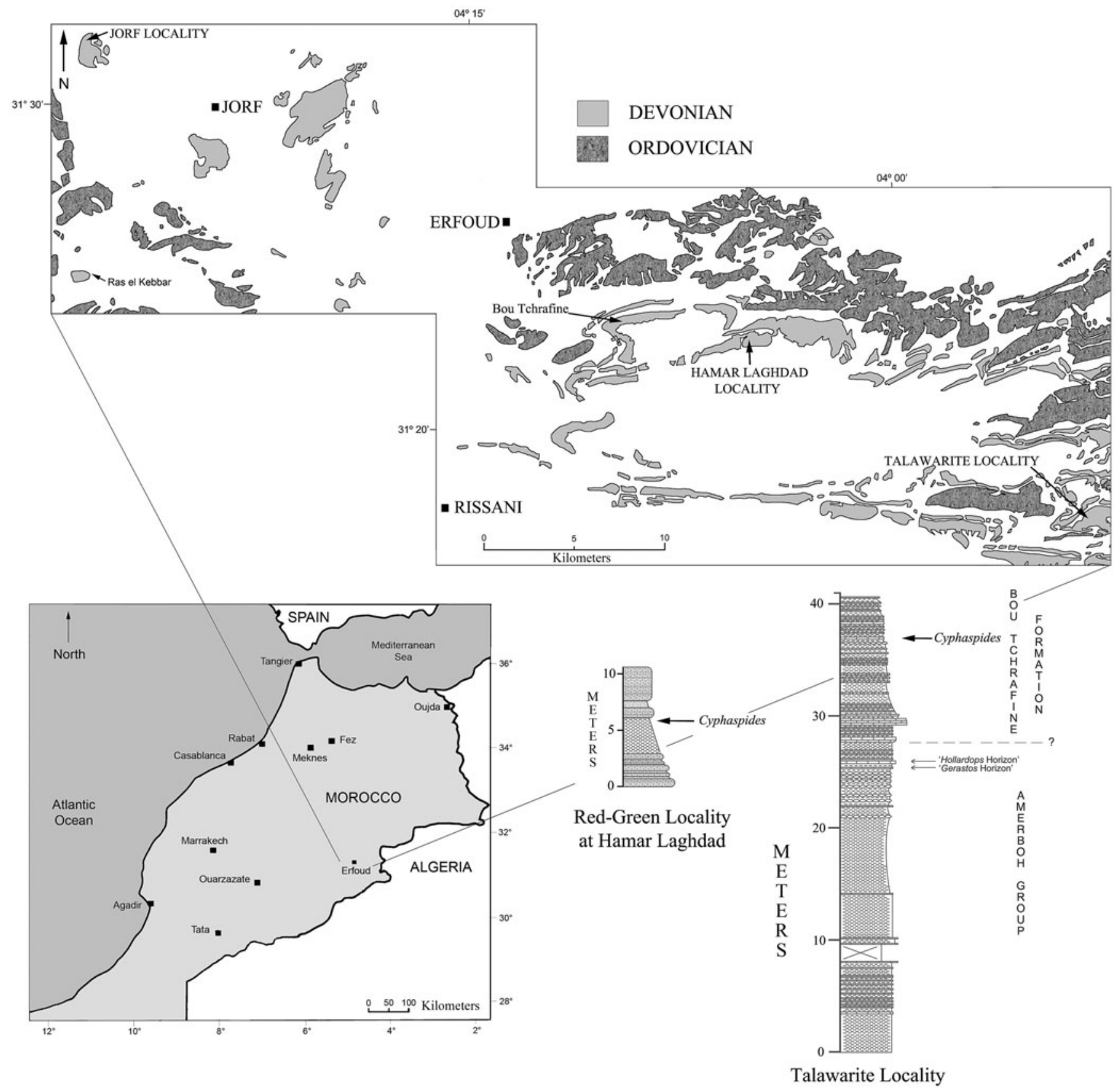

Figure 1. Map showing positions of localities in the Tafilalt, southeastern Morocco, that contain the species of Cyphaspides described herein. The two lithological columns are for parts of the sections at the "Red-Green" locality at Hamar Laghdad and at Talawarite. The lithological symbols in the columns are standard for sedimentary stratigraphic columns (brick symbols for limestone, horizontal lines or dashed lines for shale, and so forth), with the widths of the columns implying resistance to weathering.

We have examined the locality at Jorf that produced the specimens of Cyphaspides and found a constrained section (about $15 \mathrm{~m}$ in thickness) of limestone, where one interval of less than $2 \mathrm{~m}$ has been mined extensively. Presumably, this is the locality that produced most, if not all, of the specimens of Cyphaspides (both our specimens and those posted on the Internet that are purportedly from Jorf). The matrix of our specimens from Jorf matches the matrix of the rocks mined from this level. The first author was informed by miners at this site, when he visited in 2014, that this locality was primarily mined for the lichid trilobite Basseiarges mellishae Corbacho and López-Soriano,
2013. Corbacho and López-Soriano (2013) considered B. mellishae to be Middle Devonian in age.

The late Early Devonian to Middle Devonian was a period when Cyphaspides was evolving and radiating rapidly. The genus has a stratigraphic range from Pragian to Middle Givetian (although some workers have suggested that its range may extend into the Late Devonian). The comparatively limited stratigraphic range of this genus is not surprising for a taxon with some characteristics that we consider unusual for the family and that likely are derived for the Aulacopleuridae (fused facial sutures, small stalked eyes, minute or indistinct L1 lobes, and marginal spinose tubercles). 
A recent work by Basse and Müller (2016) described two new species of Cyphaspides from Germany on the basis of wellpreserved and largely articulated specimens. Another articulated specimen of Cyphaspides from Germany was illustrated by Lawrence and Stammers (2014). The description and illustration of these new articulated specimens has substantially improved our knowledge and understanding of Cyphaspides (see the following). However, many of the other named species of this genus, including the type species, are based on disarticulated sclerites (often just a cranidium or a pygidium) or incomplete or poorly preserved carapaces. The goal of the current work, which is based on largely complete individuals, is to improve our understanding of Cyphaspides.

The potential for a phylogenetic analysis of Cyphaspides is currently limited by problems with outgroup choice and character polarity. Cyphaspides is distinct enough morphologically from other members of the Aulacopleuridae to be placed in its own subfamily; the only taxon regarded as similar enough to Cyphaspides to be included in the same subfamily is Protocyphaspides. Protocyphaspides differs from Cyphaspides mainly in having a functioning facial suture (but some authors have regarded Protocyphaspides as a junior subjective synonym of Cyphaspides, see the following).

Some Devonian and Carboniferous aulacopleurid and brachymetopid trilobites have fused facial sutures and may have marginal cephalic and pygidial spines and reduced glabellar lobes. Taxa such as Coignouina and Brachymetopus appear similar to some species of Cyphaspides but are just as likely to be convergent upon Cyphaspides species as they are to be closely related to them. These genera are younger than Cyphaspides and therefore not suitable candidates for being considered an ancestor of Cyphaspides. They are also so much later in age than Cyphaspides that consideration as a sister group or descendant relationship to Cyphaspides would require a large undiscovered range for one or more of these taxa (i.e., extensive Lazarus species). We have a limited knowledge of the ontogeny of Cyphaspides (see the following). At present, we lack information on such features as the form of the hypostome (aulacopleurid hypostomes are usually rather simple and not particularly distinctive or useful for taxonomy), and the nature of the ventral connective sutures (it is presumed that there is no rostral plate as the sutures are probably fused, which is usually the case when dorsal facial sutures are fused). All these factors render it difficult to choose a suitable outgroup for a phylogenetic analysis or to suggest reasonable ancestral versus derived character states for many of the potential characters to be used in such an analysis. For these reasons, we have not attempted a phylogenetic analysis at this time. When additional well-preserved taxa belonging to this genus and/or other closely related genera are discovered, and better preserved or more complete topotypes are collected for some of the named but poorly known species, such an analysis will be useful to posit relationships among cyphaspidines and other closely related aulacopleurids.

\section{Paleobiogeography}

Cyphaspides has been found in North Africa (Morocco), northwestern France, Germany, the Czech Republic, Uzbekistan, and
South China. All of these regions were located within 50 degrees of the paleoequator during the early Middle Devonian (see Golonka, 2002). All of the regions where Cyphaspides has been found occur close to ancient current gyres posited by various authors (Golonka et al., 1994, figs. 22, 23; 2002, fig. 6; Copper, 2002; Gluchowski and Racki, 2005, fig. 6) on the basis of the paleomagnetic positions of the continents, Devonian faunal and/or floral distributions, and the occurrences of such ancient climatic indicators as evaporites, phosphates, tillites or diamictites, coals, and so on. Using these paleogeographic maps, we posit that Cyphaspides may, in future, be found in upper Lower or Middle Devonian strata of some of the following regions: Afghanistan, Apulia, elsewhere in Europe (e.g., Austria, Belgium, and Spain), Iran, elsewhere in North Africa (e.g., Algeria and Tunisia), Tibet, and Turkey.

Other workers, including Richter and Richter (1943), Alberti (1964, 1967, 1969, 1970, 1981, 1983), Chatterton et al. (2006), McKellar and Chatterton (2009), and Gibb and Chatterton (2010), have previously noted the similarity between German and Czech Early and Middle Devonian trilobite faunas and those from Morocco. Clearly, migration and genetic exchange was possible between these regions. Basse and Müller (2016) also commented on the biogeographic distributions of Cyphaspides, mainly in the discussions of their new species.

Cyphaspides has not been found on the northern side of the Rheic Ocean. We posit therefore that it is less likely to be found in such regions of the Devonian northern hemisphere as Greenland, Inner Mongolia, Northern China, the Amur River part of Russia, Laurussia, the Salair River, and the Altai Range.

\section{Stratigraphy}

The beds that contain the three species of Cyphaspides proposed herein are all of Eifelian age and have been assigned to the Bou Tchrafine Group. The type section of this group is presumably located on Jbel Bou Tchrafine, a small ridge/mountain located east and northeast of the small town of Jorf, west of Erfoud in the Province of Errachidia, southeastern Morocco (see Fig. 1). Jbel Bou Tchrafine is almost equidistant between the Jorf and the Hamar Laghdad localities. The Bou Tchrafine Group first appeared in the literature in a stratigraphic column published by Hollard (1981, table 4). This paper was published posthumously (submitted for publication by Solange Willefert; see Hollard, 1981, p. 23), based on Hollard's notes, and the paper consists of a single page of text and five correlation tables. The group has not been formally described or proposed. In Hollard's (1981) work, the Bou Tchrafine Group is shown as being correlative with the upper El Otfal Formation, the Taboumaklouf Formation, and the lower Bou Dib Formation of the Ma'der Region (south of the Erfoud region; Fig. 1) and is Eifelian (Couvinian) to Givetian in age. In Hollard's (1981, table 4) paper, the Bou Tchrafine Group is subdivided into five informal formations (from bottom to top: Corniche inférieure [lower cornice: gray limestone with goniatites and bivalves; the name implies that it is a resistant unit]; Talus median [median slope: nodular limestone with pyrite, presumably not resistant]; 
Corniche supérieur [upper cornice: gray limestone in slabs, followed by limestone and marl and then by limestone in large benches; another resistant unit]; Couverture de la corniche [cover of cornice: black limestone in large beds, shelly limestone, and thin-bedded gray limestone]; and finally by the 'Mance Combe au talus' (thin valley of talus: light greenish limestone, presumably a recessive unit]). The group is a useful, mappable unit in the region north, east, and west of Erfoud. In a slightly earlier publication, Bultynck and Hollard (1980, fig. 3) included strata of the same age with similar descriptions of the strata from the Tafilalt Region, 'Region d'Erfoud' (that presumably includes the present study area) in the upper El Otfal and Taboumaklouf formations. The trilobite-bearing (including Cyphaspides) beds occur not far above calcareous shale and mudstone intervals assigned to the Amerboh Group, the rock unit shown by Hollard (1981, table 4) as occurring below the Bou Tchrafine Group. This suggests that the trilobites occur in the lowest formation (Cornice inférieur) of the Bou Tchrafine Group, a unit of Eifelian age. This would agree with the nature of the outcrops where the specimens of Cyphaspides described herein were collected. The age of these sections at Bou Tchrafine is fairly well known from conodonts and ammonoids that have been identified from several sections along the sides of the mountain (Bultynck and Hollard, 1980; Bultynck and Jacobs, 1981; Bensaid et al., 1985; Becker and House, 1994; Bultynck and Walliser, 2000). Bensaid et al. (1985, fig. 3) included the Bou Tchrafine Group in a diagram in a position below the Polygnathus varcus Zone (presumably Eifelian $=$ Couvinian) and noted that lower Emsian to upper Famennian strata are exposed in the Bou Tchrafine Range. Bultynck and Walliser (2000, fig. 4) showed the Bou Tchafrine Group ranging from the base of the Eifelian to mid Givetian.

The strata in the interval that contains Cyphaspides consist of gray to buff-gray limestone and argillaceous limestone that are moderately resistant to weathering. The limestones seem to be mainly mudstone and wackestone, but some beds are packstone. Occasional beds in this rock unit contain numerous articulated trilobite carapaces in a wackestone and are presumably obrution deposits. These obrution deposits may or may not have moved penecontemporaneously (the trilobites may be parallel to bedding when they have not moved, or they may be oriented in chaotic orientations relative to the bedding planes where mass wastage has occurred). We believe that most, if not all, of these beds were deposited below fair-weather wave base but that some of them were disturbed by occasional storm events (i.e., above storm wave base). This is fairly typical of the Early and Middle Devonian strata in this region of Morocco that contain abundant articulated trilobite carapaces (see Chatterton et al., 2006; Brett et al., 2012). Some of the trilobites, including Cyphaspides and other fossils in the same beds, at both the Talawarite and Red-Green localities, are silicified (at least the surfaces of their sclerites). This suggests that the sediments originally contained opaline silica-bearing parts of organisms-most likely siliceous sponges or radiolarians. Both of these types of organisms are more abundant in environments of moderate or greater depth (below fair-weather wave base) in the sea, rather than in shallow, near-shore environments.

\section{Ontogeny}

We do not have a complete ontogenetic sequence that extends from larval (protaspid) to holaspid stages for any species of Cyphaspides. However, we do illustrate some small silicified growth stages, probably from late meraspid and early holaspid stages. None of the small cephala that we found show signs of a functioning facial suture, although Basse and Müller (2016, pl. 32.335) illustrated a small cranidium that may have the free cheeks separated from it and a larger free cheek (2016, pl. 32.336) that does not appear to be attached to a cranidium. They assigned these specimens to their 'Cyphaspides (Cyphaspides) n. sp. M.' However, the margins of these specimens are not clearly shown in their illustrations and could be the result of fracturing rather than separation along a functioning facial suture. Basse and Müller (2016) pointed out that the most important feature separating Protocyphaspides from Cyphaspides is the presence of a functioning facial suture. However, they placed their form in Cyphaspides (Cyphaspides) despite suggesting that two of their specimens may have a functioning facial suture.

Allometric changes visible on some of the material available to us suggest that with growth the background sculpture of granules increases in coarseness to tubercles, marginal spines become marginal spinose tubercles or tubercles, L1 becomes more distinct, border furrows increase in depth, the number of pleural ribs and marginal spines increases on the pygidium, and the pygidial axial rings increase in number and distinctness. The smallest cephala available to us are large enough that there could potentially be earlier meraspid and/or protaspid stages with functioning facial sutures. At present, we do not know what sort of sutures were present in small meraspides and protaspides of this genus.

Allometric changes during the holaspid period also occur, and Basse and Müller (2016) noted that their specimens of Cyphaspides malbertii Basse and Müller, 2016 are larger than their specimens of Cyphaspides weugi Basse and Müller, 2016, implying that perhaps if the latter grew to a larger size, the differences in form might not be as great. We also suggest in the following that some undescribed forms we have observed online are rather similar to Cyphaspides nicoleae new species but have still longer and more curved (outward=laterally) genal and thoracic pleural spines and may be large or gerontic individuals of that species.

\section{Materials and methods}

All specimens, unless noted otherwise, were blackened with watercolor paint and then coated with a sublimate of ammonium chloride prior to photography. The light photographs utilized Nikon or Zeiss macro lenses with depth of field enhanced by taking a sequence of photographs at the same magnification, but at different distances from the surface of the specimen, using the 'Stackshot' system for moving the camera and lens toward or away from the specimens. The numerous photographs obtained by this method were then stacked in a computer using either 'Helicon Focus' or 'Zerene Stacker' programs. Scanning electron photomicrographs were obtained by coating specimens 
with gold and using a Jeol Scanning Electron Microscope to obtain images with backscattered electrons.

Repository and institutional abbreviation.-Type, figured, and other specimens examined in this study are deposited in the following institution: University of Alberta Paleontology Collections, Department of Earth and Atmospheric Sciences, University of Alberta, Edmonton, Alberta T6G 2E3, Canada. These specimens are provided with UA type numbers.

\section{Systematic paleontology}

Class Trilobita Walch, 1771

Order Proetida Fortey and Owens, 1975

Superfamily Aulacopleuroidea Angelin, 1854

Family Aulacopleuridae Angelin, 1854

Subfamily Cyphaspidinae Přibyl, 1947

=Cyphaspidedinae Prantl and Přibyl, 1950 (invalid nom. correct.)

Genus Cyphaspides Novák, 1890

Type species.-Cyphaspides scuticauda Novák, 1890 by subsequent designation of Vogdes, 1925, lower Middle Devonian, from the Devonian Nemecko (Greifenstein, Middle Devonian) of Germany. Type specimen is a pygidium from the Greifenstein Limestone (Eifelian), Hessen, Germany. Treatise (Moore, 1959, fig. 309 2D; other species illustrated in fig. 309A-C).

Other species.-Cyphaspides sp. from the Middle Devonian (Givetian) Hämatitischer Kalk of Germany (Basse and Lemke, 1996); Cyphaspides sp. from the upper Emsian 'Red Cliff' at Hamar Laghdad, Tafilalt, Morocco (Crônier et al., 2018); Cyphaspides ammari new species from the Middle Devonian (lower Eifelian) strata, Bou Tchrafine Group at Talawarite, northeast of Erg Chebbi in southeastern Morocco; Cyphaspides cerberus (Barrande, 1846) from the Middle Devonian Suchomasty Limestone (lower Eifelian), Koněprusy, Czech Republic; Cyphaspides comatus (Barrande, 1872) from the Dvorce-Prokop Limestone (Pragian), Praha, Czech Republic; Cyphaspides erbeni (nomen nudum) Yolkin in Kim et al. (1978a, b) from Emsian strata at Khodzhakurgan, Uzbekistan (see also Owens et al., 2010); Cyphaspides holinensis holinensis Růžička, 1939 from the Choteč Limestone, Choteč (upper Eifelian), Czech Republic (see also Basse, 1997); Cyphaspides malbertii Basse and Müller, 2016, from the Rupbach Shale (lower Eifelian), Germany; Cyphaspides nicoleae new species from the Middle Devonian (Eifelian) strata, Bou Tchrafine Group at Jorf, near Erfoud, southeastern Morocco; Cyphaspides holinensis barrandei Prantl and Prribyl, 1950 from the Acanthopyge Limestone (upper Eifelian), Koněprusy, Czech Republic; Cyphaspides novaki Prantl and Prribyl, 1950, from the Middle Devonian Suchomasty Limestone (lower Eifelian) at Koněprusy, Czech Republic; Cyphaspides orientalis Yi and Hsiang, 1975 from the Middle Devonian of China; Cyphaspides ovatus Luo and Jiang, 1985 from the Middle and Upper Devonian of China, southeastern Yunnan; Cyphaspides pankowskiorum new species from the Middle Devonian (lower Eifelian) strata, Bou
Tchrafine Group at Jorf, near Erfoud, southeastern Morocco; Cyphaspides paradoxus Yi and Hsiang, 1975 from the Middle Devonian of China; Cyphaspides svobodai Prantl and Přibyl, 1950 from the Lower Devonian Reporyje Limestone (Pragian), Klukovice, Czech Republic (Czech Republic localities and ages follow those of Horný and Bastl, 1970); and Cyphaspides weugi Basse and Müller, 2016 from the lowest Eifelian Wissenbach Shale of Germany.

A possible additional species of Cyphaspides occurs at the Jorf locality, near Erfoud, southeastern Morocco, according to specimens illustrated on the Internet, but is not formally recognized. This form is distinct in that it has very long genal spines and particularly long pleural spines in the thorax. All of the thoracic pleural spines curve laterally and/or slightly forward, distally. The marginal spines around the cephalon are long for the genus. It is most similar to Cyphaspides nicoleae new species and could be a gerontic form of that species since they appear to be large specimens and the main differences from $C$. nicoleae are the length and curvature of the thoracic pleural and genal spines, features that likely change ontogenetically.

Diagnosis.-Aulacopleurid with small, widely spaced eyes on short stalks. Facial sutures are fused in mature specimens. Glabella is inflated and widest toward anterior of frontal lobe. L1 lobes are very small. Sculpture consists of bimodal tubercles (numerous small and fewer large tubercles), with one to several rows of outward-directed slightly spinose tubercles around anterior and lateral margins of cephalon. Tubular, sharply pointed genal spines extend posterolaterally and curve slightly backward distally. Between 11 and 13 thoracic segments are present (possibly 13 segments in all species). Pleural spines on anterior thoracic segments are short and laterally directed; those on more posterior segments are longer and more posteriorly directed. Pygidium is relatively long (for family), with distinct marginal spines at tips of four or more posterior pleural ribs; several smaller marginal spines are usually present opposite end of anterior pleural rib of first pygidial segment. Low anterior and more inflated but narrow posterior pleural ribs are subtransverse proximally but curve sharply backward near their midlengths (from axis to margin). Pygidial axis contains numerous short (sagittal [sag.] and exsagittal [exsag.]) axial rings. Posterior margin of pygidium is concave medially. Row of larger tubercles occurs on posterior pleural bands of thoracic and pygidial pleurae, near or just distal to fulcral line.

Occurrence.-Pragian to Givetian strata in Europe (Czech Republic, France, Germany), Uzbekistan, South China, and North Africa (Morocco). See also extensive discussion in Basse and Müller (2016).

Remarks. - Rudolph and Emma Richter and Herta Schmidt (in Moore, 1959) included Cyphaspides in the Cyphaspidinae and the Otarionidae. More recently, Jell and Adrain (2003) included Cyphaspides in the family Aulacopleuridae. Three new species are proposed and described for this genus in the present work. These descriptions are based mainly on articulated, complete carapaces. However, we have also obtained silicified sclerites of 
this genus from the mined trilobite interval at Talawarite (complete adult carapaces that are the types of Cyphaspides ammari new species were collected from this bed) and from the locality that is known informally as the Red-Green bed at Hamar Laghdad (see Klug et al., 2009). Cyphaspides is a sufficiently distinct genus of aulacopleurid trilobite that it is classified in a subfamily with only one other similar, closely related genus, Protocyphaspides Prribyl and Vanek, 1977 and possibly the much younger Namuropyge. Protocyphaspides is very similar to Cyphaspides and was regarded as a junior synonym of Cyphaspides by Adrain and Chatterton (1994, p. 309). Namuropyge occurs in the Carboniferous, and even if it is closely related to Cyphaspides, which is doubtful at best, it is not suitable as an outgroup for a phylogenetic analysis as most of the similarities between these taxa are likely homoplasious rather than ancestral. Distinctive features of Cyphaspides are listed in the diagnosis, but of particular note are the fused facial sutures in holaspides; small, widely separated, usually stalked, and distinct eyes (without obvious lenses); marginal spines on the cephalon and pygidium; and particularly small and sometimes inconspicuous L1 lobes.

A number of the named taxa of Cyphaspides are based on only a few sclerites, such as pygidia or incomplete cephala. Beyond this material, important features that can be used to discriminate between species of Cyphaspides include the number of thoracic segments. These appear to range between 11 and 13 , but there is a possibility that specimens found with only 11 or 12 segments have the first $1-2$ segments hidden under the cephalon, so all species may have had 13 thoracic segments (see also discussion in Basse and Müller, 2016). Additional characteristics include the size, height, and distance between the eyes; details of the sculpture (density, shapes, size, and bimodality of granules and tubercles), including the number of rows of marginal tubercles on the cephalon; the relative width of the thoracic axis; the length and direction of the genal and thoracic pleural spines; the position of the row of spines on the posterior pleural bands of the pygidium (how proximal or distal they are); and the number of axial rings, marginal spines, and pleural ribs in the pygidium. The degree of fusion of the facial sutures (how easy it is to see the fused path of the suture), the presence of genal caeca, and the prominence of L1 in the glabella (completeness of S1) are also variable among species within this genus. Complete, well-preserved specimens are necessary to ascertain all of these features and to contrast species properly. This is not always possible. Many of the type specimens of previously proposed species of Cyphaspides are so incomplete or poorly preserved and/or illustrated in the literature that it is difficult to determine the states for many or most of the more diagnostic characters. Unfortunately, this situation undermines any attempt at a phylogenetic analysis of the genus (at least until better and more complete topotypes are collected for a number of the species involved). The present work provides detailed descriptions of three new species based on comparatively complete and well-preserved types. It is hoped that new morphological details provided herein along with our discussions enhance the knowledge and understanding of this genus.

Before the discovery of the articulated carapaces of Cyphaspides from Morocco, the only articulated specimens illustrated in the literature belonged to two Middle Devonian species from China and several from Germany: C. orientalis Yi and Hsiang, 1975 and C. paradoxus Yi and Hsiang, 1975 from China; a specimen identified as $C$. holinensis (Růžička, 1939) by Lawrence and Stammers (2014, p. 144) from the Emsian/Eifelian Rupbach Schiefer, Steinbrich, Gutenacker, Lahn, Eifel District; and C. malbertii Basse and Müller, 2016 and C. weugi Basse and Müller, 2016, also from the Eifelian Rupbach Slate of Germany. Specimens of C. malbertii illustrated by Basse and Müller (2016, pls. 28-29) show 11, 12, and 13 thoracic segments, with the best-articulated specimens showing 13 segments. The best-articulated specimen of $C$. weugi has 13 thoracic segments. Basse and Müller (2016) believed that both of their new species have 13 thoracic segments, and either that number of thoracic segments (13) should be included in the diagnosis for the genus or it should be left out of the diagnosis. In C. orientalis, there appear to be 12 thoracic segments (Yi and Hsiang, 1975, pl. 2, fig. 6), but the illustrated carapace is slightly disarticulated, with the posterior part of the cephalon missing, so the anteriormost thoracic segment(s) could also be missing. In C. paradoxus, there are 13 thoracic segments visible in the type specimen (Yi and Hsiang, 1975, pl. 3, fig. 1). In the articulated specimen illustrated as $C$. holinensis from Germany, there are at least 12 segments present, but here too there may have been segments obscured. The specimen is an internal mold, and is particularly distinctive because of the presence of long, well-developed eye ridges. However, eye ridges are sometimes more prominent on the internal surface of the carapace than they are on the external (dorsal) surface, and our species have been examined externally, not internally.

The type and only illustrated specimen of Cyphaspides ovatus Luo and Jiang (1985) is the anterior part of a cephalon, with comparatively few, large, and somewhat spinose tubercles on the dorsal part of the glabella and genal fields. While likely belonging to Cyphaspides, the type cephalon of $C$. ovatus is not similar to the cephala of any of the Moroccan species. More (and more complete) material of $C$. ovatus needs to be found before its relationships to other species of the genus can be determined.

\section{Cyphaspides ammari new species Figures 2, 3.1-3.7, 4}

?1969 Cyphaspides ex aff. C. holinensis Růžička, 1939, Alberti, p. 389.

?2018 Cyphaspides sp. Crônier et al., p. 252, figs. 4m-p.

Holotype.-Holotype complete articulated carapace UA14313 (Figs. 2.1-2.3, 2.5, 3.2, 3.4, 3.6, 3.7) from early Eifelian Bou Tchrafine Group at Talawarite, northeast of Erg Chebbi, near Erfoud, Province of Errachidia, southeastern Morocco (MRZ-TB).

Diagnosis. - Cyphaspides with particularly small and widely spaced eyes (eyes closer to lateral border furrows than axial furrows). Genal spines are short and sharp for genus (length $\cong$ distance from genal angle to eye). Eye ridges are wide (transverse [tr.]), short (exsag.), and more distinct close to axial furrows than they are close to eyes. Larger tubercles on 

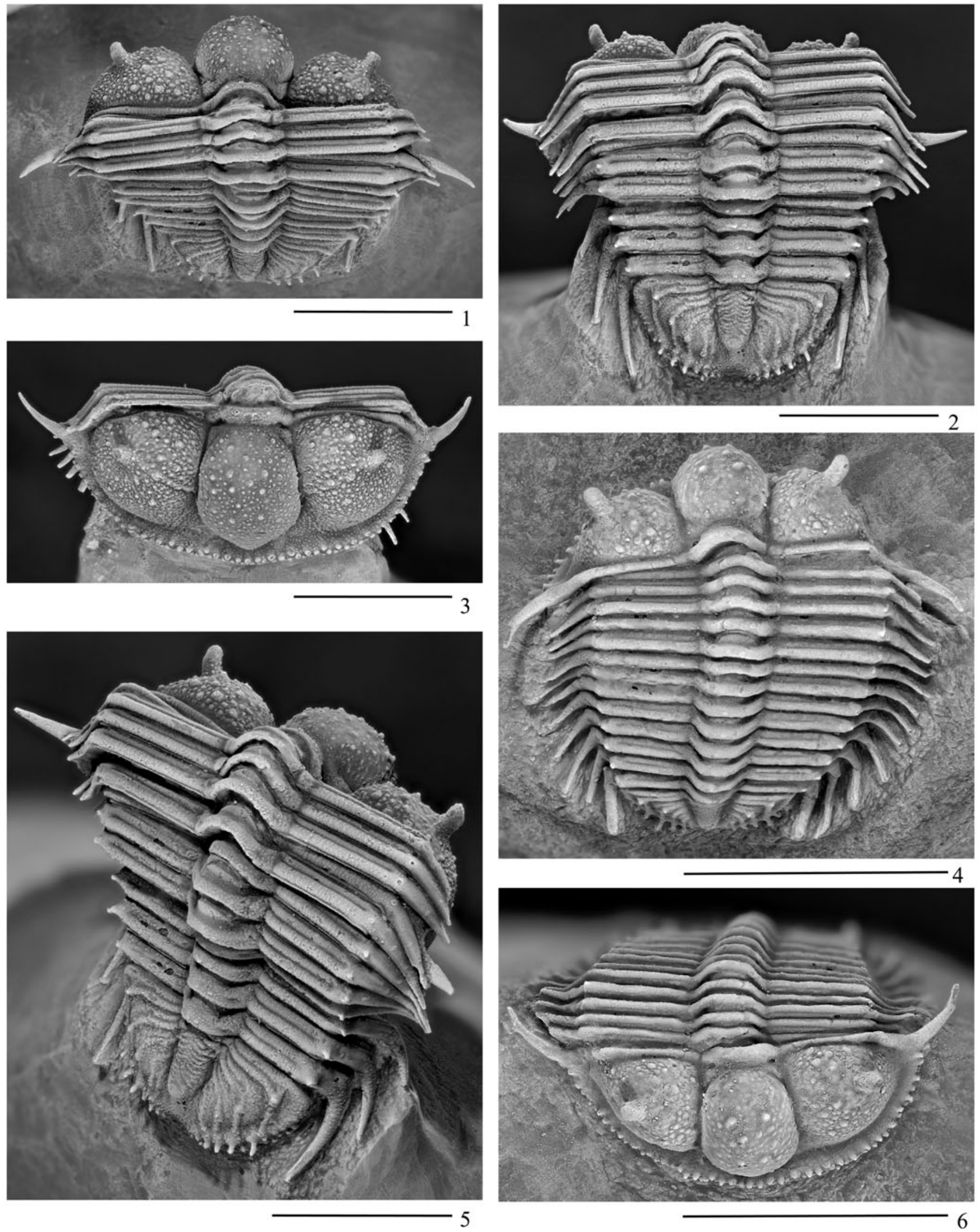

Figure 2. Cyphaspides ammari new species from the type locality, a mined trilobite bed at the Talawarite locality, east of Erfoud (Fig. 1), of Eifelian age, assigned to the Bou Tchrafine Formation. $(\mathbf{1 - 3 , 5})$ External views of articulated carapace holotype UA14313. (4, 6) External views of paratype UA14314. Scale bars $=1 \mathrm{~cm}$. 
glabella appear roughly organized into irregular transverse pairs. Smaller tubercles on genal field are aligned on weak, fine caecal ridges. There are 13 thoracic segments. Thoracic pleural spines are moderate in length and ventrolaterally directed in the front part of thorax; they are slightly longer and more posteriorly directed toward the back of the thorax, with posteriormost pleural spine extending almost as far as, but usually not behind, posterior margin of pygidium.

Occurrence.-The type locality is at GPS location $31^{\circ}$ $16^{\prime} 28.5^{\prime \prime} \mathrm{N}$ and $03^{\circ} 53^{\prime} 29.4^{\prime \prime} \mathrm{W}$. Paratypes include UA14314 (Fig. 2.4, 2.6), articulated carapace paratype UA14315 (Fig. 3.1, 3.3, 3.5), and incomplete silicified sclerite paratypes UA14318-UA14322, UA14324 (Fig. 4.1-4.5, 4.7). Additional specimens were collected from a correlative level at the Red-Green locality at Hamar Laghdad (plesiotypes UA14323, UA14268; Fig. 4.6, 4.8).

Description.-Cephalon is roughly semicircular in dorsal view, not including comparatively short, moderately curved, and sharply pointed genal spines. Facial sutures are fused in all mature (holaspid) growth stages. Margin of cephalon has at least two (2.5) rows of outwardly and dorsally directed spinose tubercles; some of these marginal tubercles are quite long and spinose when fully preserved. Frontal lobe of glabella is moderately inflated and convex anteriorly, overhanging much of anterior border but not anterior margin. L1 are small, laterally situated, and sunken below level of both inflated frontal lobe of glabella and arched occipital ring. Sculpture on frontal lobe and genal field is of tubercles that are bimodal in size, with larger tubercles showing rough bilateral pairing (symmetry) on glabella. Eyes are small, on short stalks, and widely spaced, with their midlengths situated posterior to midlength of frontal lobe and anterior to S1. Posterior margins of eyes are close to opposite where S1 sulci join axial furrows. Eye ridges are extensive (tr.), short (exsag.), and more distinct near axial furrows than laterally, adjoining axial furrows slightly anterior to midlength of frontal glabellar lobe. Axial furrows are deep and slightly divergent anteriorly, adjacent to frontal glabellar lobe, and are slightly shallower opposite L1 and L0. Posterior border furrow is short (exsag.), deep, and slightly convex backward. Genal field is moderately inflated, overhanging border furrows slightly both anterolaterally and posteromedially. Lateral border furrows are distinctly impressed, except just anterior to genal angle. Lateral borders are distinctly wider (exsag. and tr.) than posterior borders are long (exsag.). Occipital furrow is of moderate depth and slightly convex-forward medially, and anterolaterally directed and distinctly deeper distally (over apodemes?).

Hypostome is not known for this species.

Thorax consists of 13 segments. Anterior pleural spines are of moderate length and directed ventrolaterally. Distal tips of more posterior thoracic segments increase in length slightly and curve progressively more to posterior, so posteriormost thoracic segment has distinctly longer pleural spines, with distal portions directed posteriorly. Axial rings are strongly arched. Axis is comparatively narrow, making up only about $13 \%$ of maximum width of thorax on third segment. Pleural furrows are short (exsag.), transverse, and distinct, separating longer (exsag.) and more inflated posterior pleural bands from shorter, lower anterior pleural bands; they terminate near fulcrum, proximal to tubercle present on posterior pleural band, close to proximal end of pleural spine, where segment changes from horizontal portion to more sloping distal spinose portion of segment. Very short (exsag.) but distinct posterior articulating flanges run from axial furrow to fulcrum. Sculpture is sparse on thorax, mainly consisting of fine tubercles or granules.

Pygidium has length (sag.) about 50\% of width. Sculpture consists of granules and single row of fine tubercles, one on each posterior pleural rib. There are at least 12 rings plus terminal piece in axis. Axial rings are short (sag. and exsag.) and curve forward medially to produce inverted chevron pattern. Axial ring furrows are slightly shallower medially. Axis, anteriorly, is $\sim 24 \%$ maximum width of pygidium. Axial furrows are moderately impressed and converge weakly toward back of axis, where they circumscribe convex posterior margin of axis. Pleural bands curve in sigmoid pattern, initially running more transversely and then after crossing part of pleura turn sharply backward distally; relatively transverse proximal part of pleural band is wider (tr.) in anterior pygidial segments. Posterior pleural bands are more inflated than, but approximately same length (exsag.) as, anterior pleural bands proximally, but are shorter and backward-directed distally. Posterior pleural bands of first four to five segments extend from margin as distinct short spine of moderate size (four to five pairs). Smaller spines project from margin in both more medial positions (around three pairs) and farther forward from lateral margin of pygidium opposite anterior pleural band of first segment (around eight pairs). Distinct dorsal tubercle is present on posteriorly directed part of each posterior pleural band of first four to five pygidial segments, forming row that curves backward and inward. Shallow border furrow runs close to margin across anterior pleural bands of segments and is less impressed into posterior pleural bands.

Etymology.-This species is named for Ammar Ait H'Ssaine, preparator of trilobites who, like his brother Hammi, possesses a tremendous knowledge of trilobites and their occurrences throughout the Anti-Atlas region of southeastern Morocco.

Remarks.-The three new Moroccan species of Cyphaspides are similar to one another. They differ in some of the character states listed in the Remarks under the genus. More detailed differential diagnoses are provided under the other new species descriptions. The pygidium of 'Cyphaspides sp.' illustrated by Alberti (1969, pl. 46, fig. 20), which is probably from the Eifelian ('Wahrscheinlich Eifelium'; Upper-Eifelian?) strata at Hamar Laghdad V, near Erfoud, differs from those of the other Moroccan species in having six well-defined pairs of posterior pygidial pleural ribs (probably with more prominent marginal spines) and in having the row of larger tubercles on those ribs that are slightly more proximally placed, close to the point of geniculation on the ribs. Alberti (1969, p. 389) considered his specimens too incomplete to assign them to a species with confidence but suggested that they show some affinity to Cyphaspides holinensis Růžička, 1939. Small silicified pygidia of Cyphaspides from the same region in the 

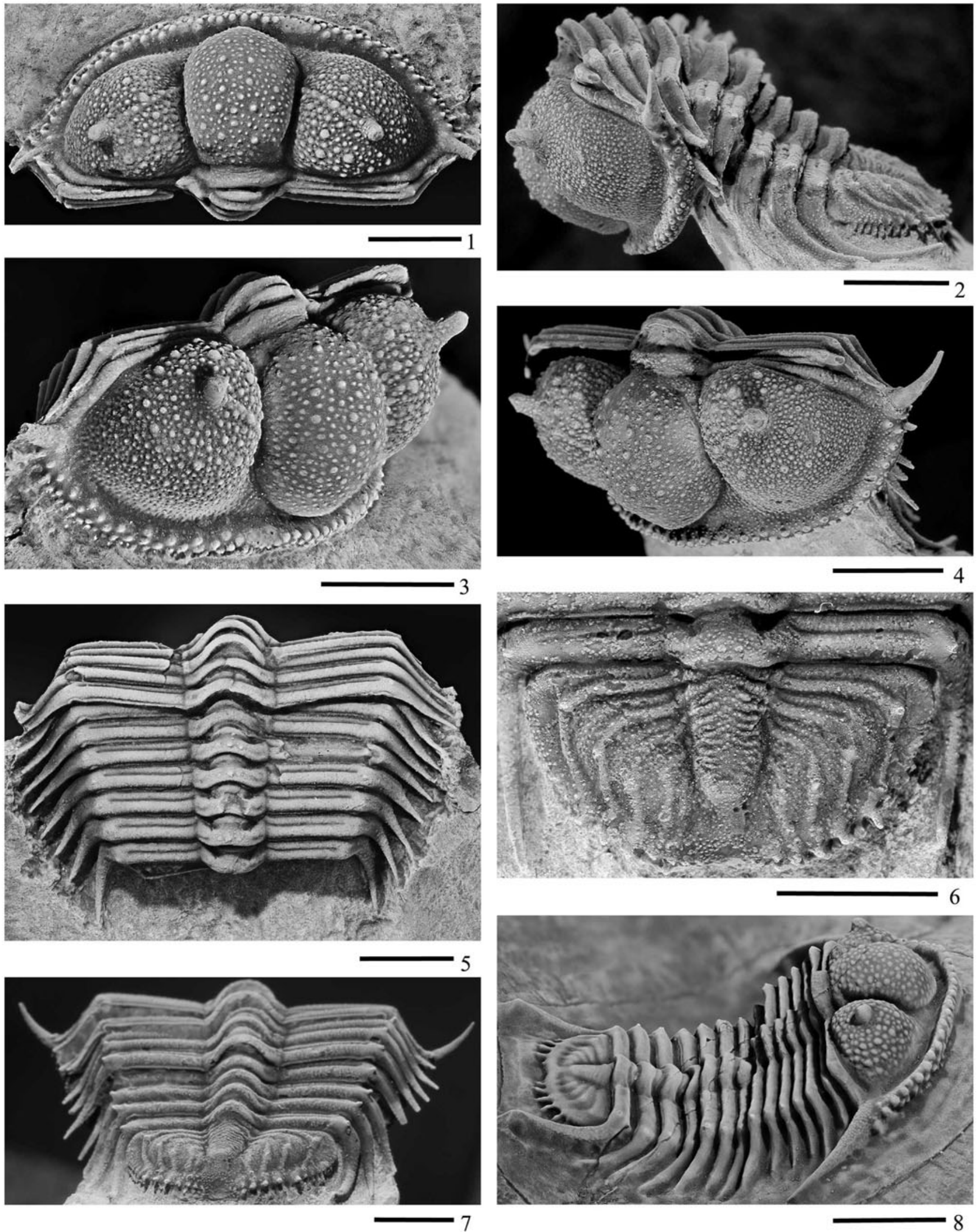

Figure 3. Photographs of Cyphaspides. (1-7) Cyphaspides ammari new species from the type locality, a mined trilobite bed at the Talawarite locality, east of Erfoud (Fig. 1), of Eifelian age, assigned to the Bou Tchrafine Formation. $(\mathbf{1 , 3 , 5})$ External views of paratype UA14315. (2, 4, 6, 7) External and posterior views of holotype UA14313. (8) Cyphaspides pankowskiorum new species from the mined trilobite bed about $6 \mathrm{~km}$ northwest of the small town of Jorf (Fig. 1), the Bou Tchrafine Formation, of Eifelian age. Dorsolateral view of the holotype UA14316. Scale bars $=5 \mathrm{~mm}$. 

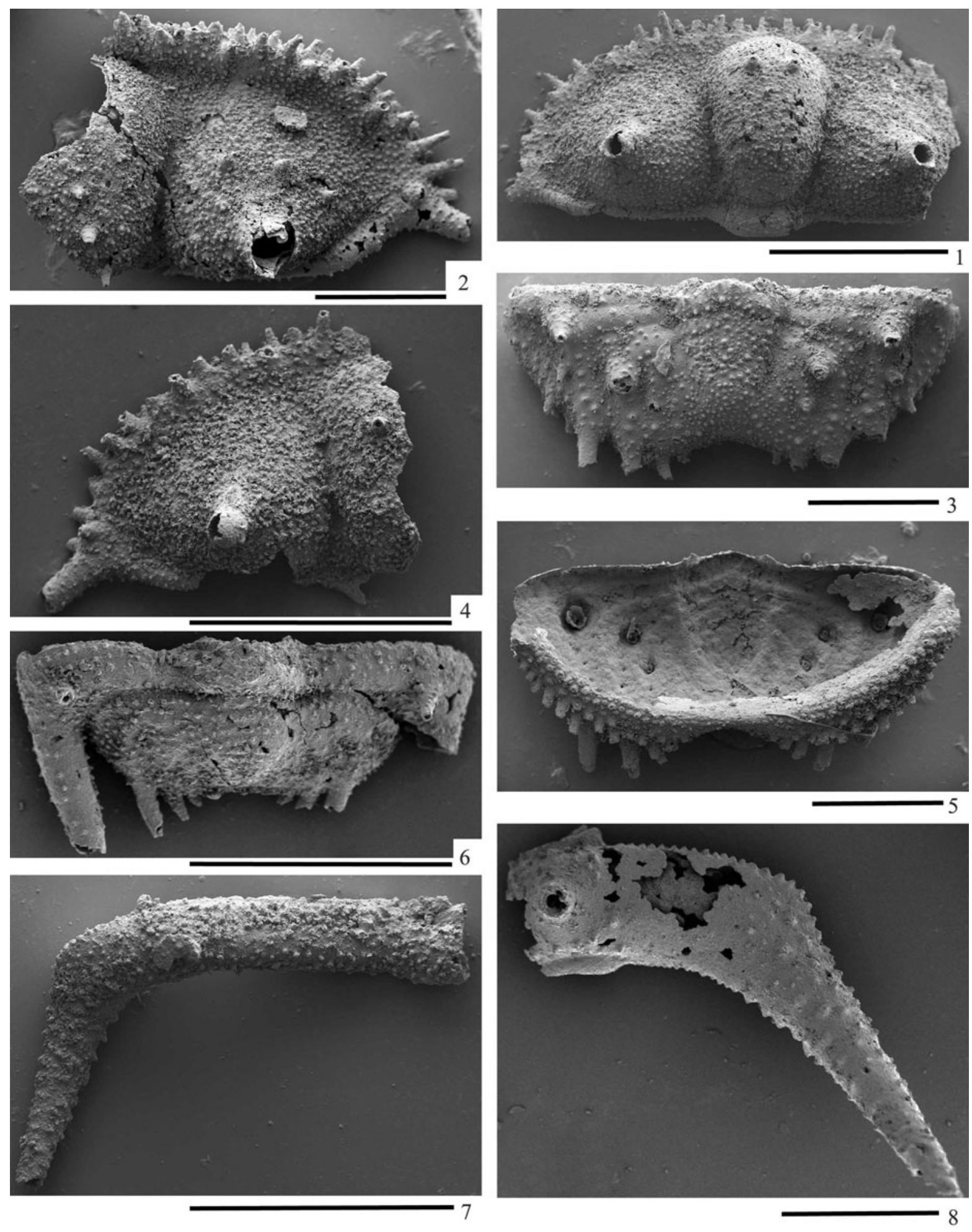

Figure 4. (1-8) Cyphaspides ammari new species. (1-5,7) From the mined trilobite bed at Talawarite locality (Fig. 1), of early Eifelian age, belonging to the Bou Tchrafine Formation, close to the top of the mountain. $(\mathbf{6 , 8})$ From the trilobite beds where phacopid trilobites that are red in color are sometimes preserved with greenish eye lenses at Hamar Laghdad (Red-Green Hamar Laghdad locality in Fig. 1), of Eifelian age, also from the Bou Tchrafine Formation. (1) Dorsal view of incomplete cephalon, paratype UA14318. (2) Dorsal view of fragment of cephalon, paratype UA14319. (3) Dorsal view of small pygidium, paratype UA14320. (4) Dorsal view of fragment of cephalon, paratype UA14321. (5) Ventral view of small pygidium, paratype UA14322. (6) Dorsal view of transitory pygidium, plesiotype UA14323. (7) Dorsal view of fragment (left pleura) of small thoracic segment, paratype UA14324. (8) Dorsal view of fragment (right pleura) of thoracic segment, plesiotype UA14268. Scale bars $=1 \mathrm{~mm}$. 
Red-Green bed have fewer distinct posterior pleural ribs on the pygidium. It is possible that the number of prominent posterior pleural ribs on the pygidium increases from small to large holaspid stages (certainly, small holaspid pygidia illustrated in Fig. 4, have fewer pleural ribs than larger holaspid pygidia from the same bed, illustrated in Fig. 2). Růžička (1939) illustrated several specimens of his new species, Cyphaspides holinensis, including a hypostome that appears rather styginid or scutelluid in form (so it may not be correctly assigned to this genus). The Moroccan species of Cyphaspides that is most similar to C. holinensis is C. ammari (sharing comparatively short genal spines and stalked eyes that are quite far apart). C. holinensis differs from all Moroccan species of Cyphaspides in having a greater number of posterior pleural ribs on the pygidium. It also differs from $C$. ammari in lacking as distinct a pattern of coarse tubercles in the prosopon and having eyes that are not as close to the lateral border furrows.

Cyphaspides ammari $\mathrm{n}$. sp. differs from C. malbertii Basse and Müller, 2016 (from the Eifelian of Germany, see above) in a number of features: L1 lobes are more distinct and better developed; the tubercles on the cephalon are slightly coarser and more distinctly bimodal in size; the glabella and thoracic axis are relatively wider in comparison to the genal and pleural regions; and there are fewer pleural ribs, with fewer marginal spines on the pygidium. These species share a slightly angular (pointed) front to the glabella, comparatively short, curved, and pointed genal spines, widely separated eyes on short stalks, 13 thoracic segments, and a distinct row of tubercles at the fulcrum on the thorax and pygidium. C. ammari is probably more similar in form to C. weugi Basse and Müller, 2016 (from the Eifelian of Germany, see the preceding), but these species differ in that the L1 lobe is more distinct in C. ammari, with the eyes slightly farther apart on the fixigenae. They are similar in age and are likely closely related.

Cyphaspides ammari $\mathrm{n}$. sp. differs from the type species of Cyphaspides, C. scuticauda Novák, 1890, from the Eifelian of Germany (see the preceding), in having fewer distinct posterior pleural ribs on the pygidium (four to five versus six); a distinct tubercle on each of the three to four more anterior posterior pleural ribs of the pygidium, near the fulcrum anteriorly; and pygidial axial furrows that are less distinct medially. The type species is known only from its pygidium.

Cyphaspides cerberus (Barrande, 1846) from the Lower Devonian of Vinarice in the Czech Republic is known from its cephalon (Barrande, 1852, pl. 18, figs. 49, 50; Prantl and Přibyl, 1950, pl. 4, fig. 6; Přibyl in Moore, 1959, fig. 309, 2ac). C. cerberus differs from C. ammari in that the eyes are closer together (tr.), the track of the fused facial suture is more distinct, the base of the genal spine is stouter, the glabella does not extend as far anteriorly over the anterior border, and the L1 lobes are not distinct.

Cyphaspides comatus (Barrande, 1872) has been mentioned and/or illustrated by several workers, including Růžička (1939), Přibyl (1949), and Prantl and Přibyl (1950). Available material of $C$. comatus appears to be an incomplete cranidium and a pygidium. The hypostome assigned to this species by Prantl and Prribyl (1950, pl. 5, figs. 8-11) probably belongs to a scutelluid trilobite and not to an aulacopleurid such as
Cyphaspides. C. ammari differs from C. comatus in that the front of the glabella extends farther forward over the anterior border; the row of dorsal spines on the pygidial pleural field is near the midpoint across the pleural field, and not near the margin; and there are fewer pleural ribs on the pygidium at the same size (four to five versus six to seven), but there appears to be a greater number of pygidial axial rings (determination of the states of this character may be affected by the quality of preservation of the types of the two species).

The poor quality of the types of C. novaki and C. svobodai (incomplete cephala), both proposed by Prantl and Přibyl (1950), renders meaningful comparisons with them difficult. However, C. svobodai has a strongly anteriorly expanded frontal lobe to the glabella (Prantl and Prribyl, 1950, pl. 3, fig. 8), a feature not found on any of our Moroccan species.

Cyphaspides ammari $\mathrm{n}$. sp. is the most similar of the three Moroccan species to two Middle Devonian species of Cyphaspides from south China described by Yi and Hsiang (1975): C. orientalis Yi and Hsiang, 1975 and C. paradoxus Yi and Hsiang, 1975. C. orientalis differs from C. ammari in the following: there may be one fewer thoracic segment; the eyes are much smaller and less apparent (difficult to discern and possibly absent in Yi and Hsiang, 1975, pl. 2, fig. 5); the genal angle is farther forward on the cephalon; the genal spines appear to be shorter; the larger tubercles in the sculpture are more prominent; and the row of spines on the posterior pygidial pleural ribs is placed slightly more proximally, where the pleural ribs curve sharply backward. The thoracic pleural spines of these two species are fairly similar, but the posteriormost of these in C. ammari may be slightly longer than those of C. orientalis. C. paradoxus Yi and Hsiang is slightly more difficult to contrast with $C$. ammari as the articulated specimen appears to be an internal mold lacking most of the exoskeleton, and the specimen is slightly flattened and distorted ( $\mathrm{Yi}$ and Hsiang, 1975, pl. 3, fig. 1). C. paradoxus differs from C. ammari in the following: the eyes are placed closer together; the frontal lobe of the glabella seems to be slightly more expanded anteriorly in dorsal view; and there are fewer posterior pleural ribs visible on the pygidium.

Cyphaspides ammari $\mathrm{n}$. sp. also shows distinct affinities with a specimen of similar age identified as Cyphaspides holinensis Růžička, 1939 by Lawrence and Stammers (2014, p. 144) from Emsian/Eifelian-aged strata in the Eifel District of Germany. Both of these forms have distinct eye ridges and comparatively short genal and thoracic pleural spines. Because the German specimen is rather flattened and only an internal mold, it is difficult to compare details of the amount of inflation, length/width ratios, number and lengths of marginal spines on the pygidium, and details of the external sculpture of these forms. The German form may have fewer distinct posterior pleural ribs in the pygidium and appears to have more distinct L1 lobes in the glabella.

Silicified sclerites of Cyphaspides ammari n. sp. were obtained from two localities (Fig. 4). Most of the specimens are small, and few are complete. They provide some ontogenetic information: small, probably early holaspid or late degree meraspid, cephala of this species already have fused facial sutures (Fig. 4.1, 4.2); L1 lobes are not well developed, eye ridges are very low or imperceptible, and genal fields are less inflated in 
small cephala (Fig. 4.1, 4.2, 4.4); bimodal nature of tubercles in prosopon is particularly pronounced in small growth stages; in small pygidia (Fig. 4.3, 4.5), axial ring furrows are less pronounced, so positions of axial rings are delineated by rows of granules, axial furrows are shallow, posterior border furrow is very shallow and barely perceptible, and there are fewer distinct pleural ribs.

\section{Cyphaspides nicoleae new species}

Figure 5.3, 5.5, 5.7

Holotype.-Holotype is complete articulated carapace UA14317 (Fig. 5.3, 5.5, 5.7) from locality close to the highway (south side), west of Jorf, near Erfoud, Province of Errachidia, southeastern Morocco (GPS: $31^{\circ} 31^{\prime} 35.8^{\prime}$ 'N, $04^{\circ}$ $28^{\prime} 03.5^{\prime}$ ' $\mathrm{W}$ ), about $6.3 \mathrm{~km}$ from Jorf and $27 \mathrm{~km}$ from Erfoud.

Diagnosis.-Cyphaspides with long, tubular genal and thoracic pleural spines. Thoracic pleural spines increase in length distinctly toward posterior of thorax and curve laterally distally, but ends of most posterior segments still extend some distance posterior to pygidium. Genal spines curve backward and upward distally. Single irregular row of spinose tubercles projects outward from margin of cephalon. Small eyes on short stalks are roughly equidistant between axial furrow and genal angle. There are at least 11 segments in thorax. Four distinct posterior pleural bands are present on pygidium. Paired larger tubercles are present on glabella and thoracic axial rings.

Description.-Cephalon has transverse, lenticular outline in dorsal view, with comparatively long, curved (posteriorly and dorsally) genal spines with tips extending back to opposite tips of thoracic segment 6 or 7. Facial suture is fused. Sculpture is bimodal, with distinctly larger tubercles and numerous smaller tubercles. Larger tubercles are arranged roughly in pairs displaying bilateral symmetry. Coarser tubercles are present on cephalon (glabella and genal fields), on axial rings of thorax, and as row of single tubercles on posterior pleural rib of each thoracic segment, near fulcrum. Spinose tubercles arranged in single row radiate slightly below horizontal plane from anterior margin of cephalon. Anterior margin of cephalon is distinctly convex-forward medially. Frontal glabellar lobe is swollen, strongly convex anteriorly, and overhangs posterior half of anterior border medially. L1 lobes are small but distinct at posterolateral corners of expanded frontal lobe. Eyes are moderate in size for genus, raised on short stalks, and located in positions that are approximately equidistant to genal angle and axial furrow. Eye ridges are obscure. Anterior and lateral border furrows are of moderate depth but shallow at genal angle. Anterior and lateral borders are of moderate width and close to horizontal (slightly raised distally). Posterior border furrow is deeper than anterior or lateral border furrow but also shallows at genal angle. Posterior border is short (exsag.) and transverse proximally and rather longer and anterolaterally directed laterally. Sculpture on posterior border is slightly more distinct than that on anterior and lateral borders. Axial furrows are deep and slightly divergent anteriorly, opposite frontal lobe of glabella; they are of similar to shallower depth and slightly divergent posteriorly, opposite L1 and occipital ring. Occipital ring is short (sag.), of similar length medially and laterally, and while distinctly arched, it is not nearly as high as frontal glabellar lobe. Genal fields are swollen, particularly posteromedially.

Hypostome is not known.

Thorax is composed of 11 segments (but see Remarks). Tubular pleural spines of anteriormost thoracic segments are comparatively short and directed ventrolaterally; those of more posterior segments are longer and more posteriorly directed, with degree of lateral curvature distally. Pleural spines of 10th segment extend posterior to pygidium, and those of 11th segment extend farther posterior to pygidium. Bilaterally symmetrical pairs of larger tubercles occur on thoracic axial rings. Each thoracic segment has larger tubercle present on posterior pleural band, close to position of fulcrum. Some segments have other, slightly smaller, tubercles close to this tubercle. Posterior pleural band is slightly longer (exsag.) and distinctly higher than anterior pleural band.

Length of pygidium is $~ 40 \%$ of its width. Maximum width of pygidial axis is $\sim 26 \%$ maximum width of pygidium. Shape of pygidium, without spines, is close to semicircular, with narrow concave posteromedian portion. Four distinct pairs of marginal spines project subhorizontally from distal ends of four slightly raised, narrow (exsag.) posterior pleural ribs; smaller spines project from margin medial to these spines, and several pairs of small spines project posterolaterally from anterolateral margin of pygidium opposite anterior pleural band of first segment. Small fifth posterior pleural rib can be discriminated in some specimens. Anterior pleural bands of pygidium are longer (exsag.) than raised posterior pleural bands, particularly distally and anteriorly in pygidium (most extreme on first segment). Pair of larger tubercles is present on each pair of posterior pleural ribs, close to point where orientation of ribs transforms from more transverse or posterolateral direction to posterior direction (extension of row of tubercles that runs down fulcral region of thorax). Axial furrows are of moderate depth, fairly straight, and converging posteriorly to give pygidial axis appearance of acute triangle. Eight or more fine axial rings and terminal piece are present in axis. Posterior border furrow is distinct but shallow across anterior pleural bands, delineating narrow posterior border.

Etymology.-This species is named for Nicole Chatterton, teacher and daughter of the first author, who sometimes entertains her pupils with stories about fossils.

Remarks.-Cyphaspides nicoleae n. $\mathrm{sp}$ differs from Cyphaspides ammari $\mathrm{n}$. sp. in that $C$. nicoleae has two fewer thoracic segments (11 versus 13, although see Remarks under genus-sometimes anteriormost thoracic segments may be hidden under cephalon in otherwise articulated specimens), distinctly longer genal and thoracic pleural spines, and more posterior thoracic pleural spines curve slightly laterally distally; the difference in size between larger and smaller tubercles in sculpture is greater (on cephalon and thoracic axis); eyes are closer together and slightly larger; there are fewer rows of marginal spinose tubercles on cephalon; there may be one fewer pair of pleural ribs on the pygidium; and pygidial axial furrows converge more strongly posteriorly. 

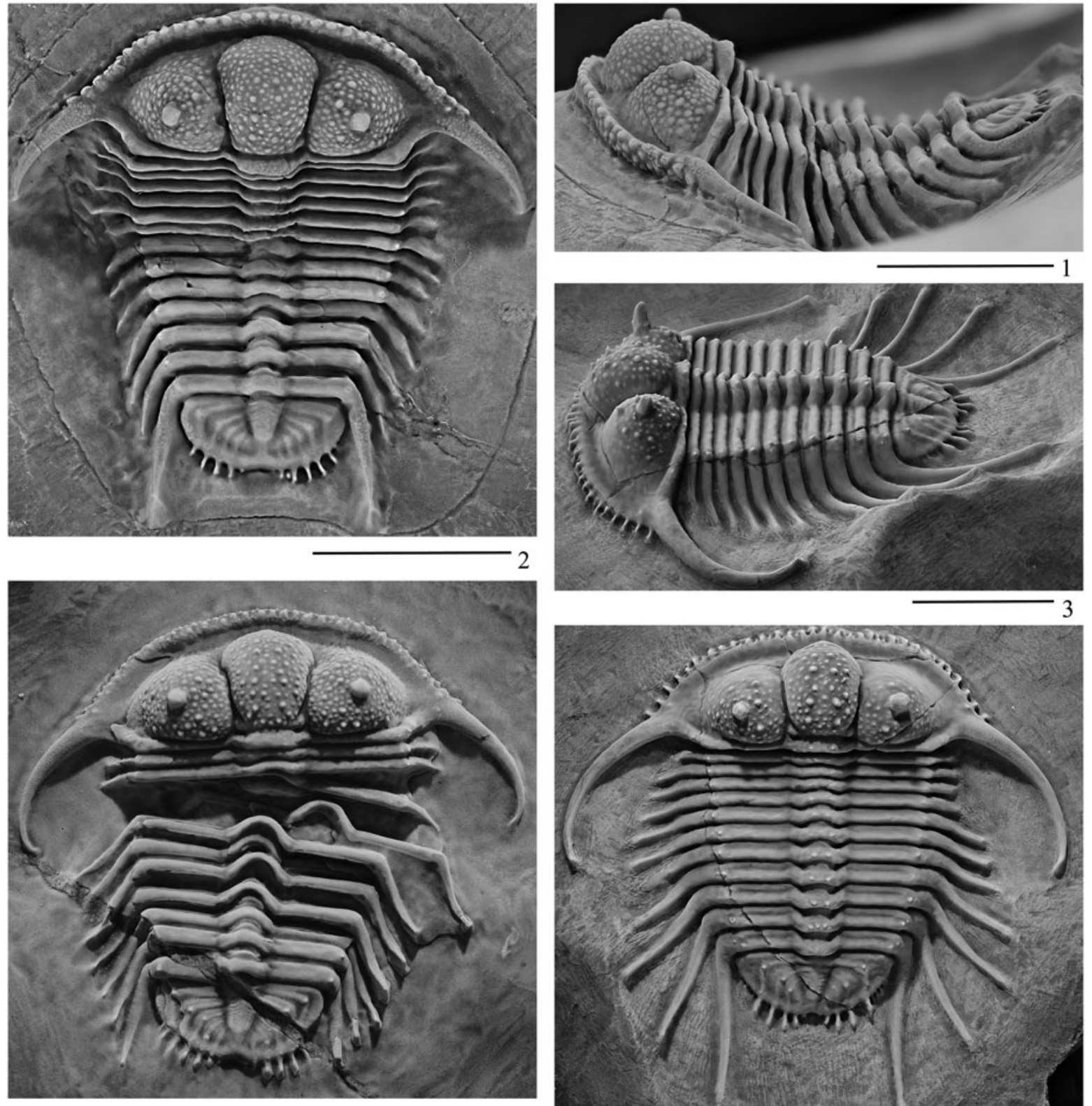

4
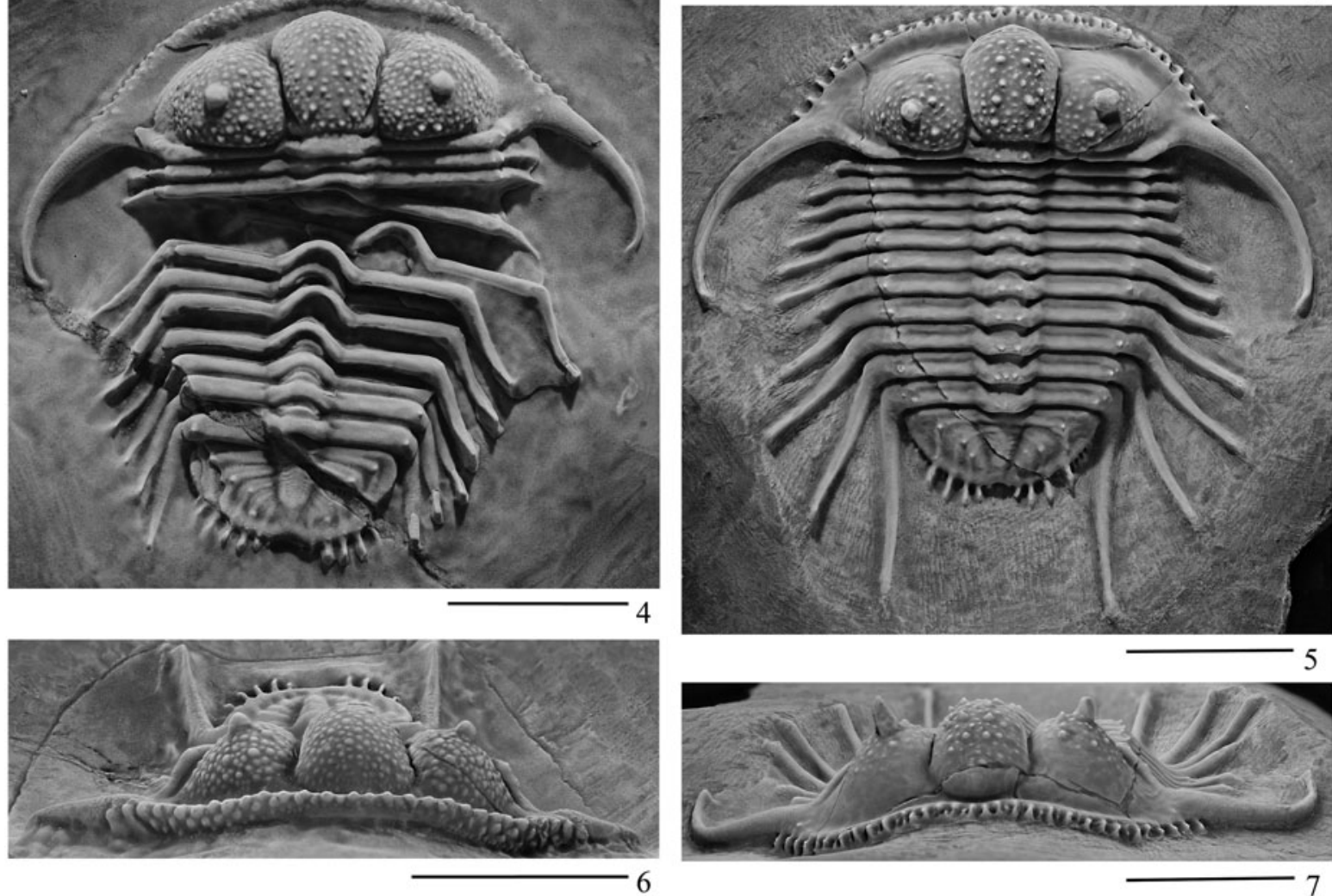

Figure 5. Cyphaspides from the mined trilobite bed, about $6 \mathrm{~km}$ northwest of the small town of Jorf (Fig. 1), Bou Tchrafine Formation, of Eifelian age. (1, 2, 6) Dorsal, left lateral, and anterior views of holotype of Cyphaspides pankowskiorum n. sp., UA14316. (4) Dorsal view of paratype UA14264. (3, 5, 7) Dorsolateral, dorsal (with coating), and anterior views of holotype of Cyphaspides nicoleae n. sp., UA14317. Scale bars $=1 \mathrm{~cm}$.

C. nicoleae $\mathrm{n}$. sp. is similar to an undescribed form that occurs in the Jorf region, which we have seen illustrated on the Internet. Specimens of the undescribed form differ from C. nicoleae in that they have 13 thoracic segments (versus 11 , but see comments in the preceding), longer and even more laterally splayed pleural spines in the thorax, and more spinose marginal tubercles on the cephalon, and the frontal glabellar lobe is so inflated that it overhangs all of the anterior border when the cephalon is viewed dorsally. Most of these differences could be the result of allometric changes taking place during 
ontogeny. As noted, there is a possibility that the two anteriormost thoracic segments are hidden under the cephalon of the holotype of $C$. nicoleae. If this proves to be the case, it is possible that these specimens with longer and more curved thoracic and genal spines, rather than belonging to a new species, are actually gerontic individuals of $C$. nicoleae.

In comparison with the two species of Cyphaspides described by Basse and Müller (2016), C. malbertii and $C$. weugi, $C$. nicoleae has much longer and more curved genal and thoracic pleural spines, a more bimodal and slightly coarser sculpture of tubercles on the glabella and genae, fewer rows of marginal spinose tubercles on the anterior and lateral margins of the cephalon, more distinct (although small) L1 lobes, a relatively wider glabella and thoracic axis, only 11 and not 13 thoracic segments (again, see comments in the preceding), and fewer pairs of pleural ribs and marginal spines on the pygidium.

\section{Cyphaspides pankowskiorum new species} Figures 3.8, 5.1, 5.2, 5.4, 5.6

2014 Cyphaspides sp. Lawrence and Stammers, p. 311.

Holotype and paratype.-Holotype complete articulated carapace UA14316 (Figs. 3.8, 5.1, 5.2, 5.6); paratype slightly disarticulated carapace UA14264 (Fig. 5.4). Type locality is close to highway (south side), west of Jorf, near Erfoud, Province of Errachidia, southeastern Morocco (31 $31^{\circ} 35.8^{\prime}{ }^{\prime} \mathrm{N}$, $\left.04^{\circ} 28^{\prime} 03.5^{\prime}, \mathrm{W}\right)$.

Diagnosis.-Cyphaspides with genal spines of moderate length. Cephalic margin with single row of tubercles medially and two or more rows of rather blunt spinose tubercles anterolaterally. Eyes are located approximately equidistant between axial furrows and genal angles. Posterior pleural bands of thoracic segments are much more inflated and longer than anterior pleural bands. Pleural spines in thorax increase in length and posterior direction posteriorly within thorax and do not turn outward distally. Posteriormost spines extend distinctly posterior to pygidium.

Description.-Cephalon has moderately transverse, lenticular outline in dorsal view, with genal spines of moderate length whose tips extend posteriorly to reach opposite tips of fifth or sixth thoracic segment. Facial suture is fused. Sculpture is weakly bimodal with few larger tubercles. Larger tubercles show weak bilateral symmetry. Slightly coarser tubercles occur on cephalon (glabella and genal fields), on axial rings of thorax, and in row of single tubercles on posterior pleural rib of each thoracic segment, near fulcrum. One to two (or even three) irregular rows of short spinose tubercles radiate subhorizontally from margin of cephalon (single row present medially, and additional tubercles are added laterally; Fig. 5.6). Frontal glabellar lobe is convex anteriorly but does not overhang anterior border. L1 lobes are small and inconspicuous at posterolateral corners of frontal lobe. S1 shallows to virtually disappear posteromedially. Eyes are moderate in size, not obviously raised on stalks, and located roughly equidistant between genal angles and axial furrows. Eye ridges are barely perceptible on dorsal surface. Anterior and lateral border furrows are deep to firmly impressed and only slightly shallower at genal angle. Anterior and lateral borders are of moderate width and slope inward, being raised distally. Posterior border furrow is deep. Posterior border is short (exsag.) and transverse proximally, and rather longer and anterolaterally directed laterally. Axial furrows are deep and slightly divergent anteriorly, opposite frontal lobe of glabella; they are of similar to shallower depth and slightly divergent posteriorly adjacent to L1 and occipital ring. Occipital ring is short (sag.) and of similar length medially and laterally, and while distinctly arched is not nearly as high as frontal glabellar lobe. Genal fields are swollen, particularly posteromedially.

Hypostome is not known.

Thorax is composed of 13 segments. Tubular pleural spines of more anterior thoracic segments are comparatively short and directed ventrolaterally; those of more posterior segments are longer and more posteriorly directed, with very slight degree of posterior curvature distally. Pleural spines of 12th segment extend posteriorly to opposite midlength of pygidium, and those of 13th segment extend well posterior to pygidium. Each thoracic segment has larger tubercle present on posterior pleural band, close to position of fulcrum, at distal geniculation of segment.

Length of pygidium is $~ 45 \%$ of its width. Maximum width of pygidial axis is $\sim 24 \%$ of maximum width. Shape of pygidium, without spines, is close to or slightly longer than semicircular, with narrow concave posteromedian portion. Five distinct pairs of marginal spines project subhorizontally from distal ends of five posterior pleural ribs that are slightly dorsally inflated and narrow (exsag.); smaller spines project from pygidial margin proximal and distal to these spines. Anterior pleural bands of pygidium are longer and lower than inflated posterior pleural bands, particularly distally and anteriorly within pygidium (most extreme on first segment). Pair of larger tubercles is present on each pair of posterior pleural ribs, close to point where course of ribs transforms from more transverse or posterolateral direction to posterior direction (extension of row of tubercles that runs down fulcral region of thorax). Axial furrows are of moderate depth, fairly straight, and converging distinctly posteriorly to give pygidial axis appearance of acute triangle. A number of thin axial rings (difficult to determine exact number on holotype) and terminal piece are present in axis. Posterior border furrow is distinct but shallow across anterior pleural bands, delineating narrow posterior border.

Etymology.-This species is named for the family of Mark Pankowski, who have donated specimens of Moroccan trilobites to the University of Alberta for the purposes of our scientific research.

Remarks.-Cyphaspides pankowskiorum n. sp. differs from Cyphaspides nicoleae n. sp., which occurs with it at the Jorf locality, in the following characteristics: in C. pankowskiorum there are two extra thoracic segments (this may be an artifact of preservation, see the preceding, as cephala sometimes overlap the anteriormost thoracic segments in otherwise articulated specimens); the tubercles of the sculpture are less distinctly bimodal, and the larger tubercles are not as obviously organized into pairs; the frontal lobe of the glabella 
is wider and less protruding forward so that it does not overhang the anterior border; the L1 lobes are less distinct, as S1 shallow posteromedially; the border furrows on the cephalon are deeper, and the borders slope inward more distinctly; the genal spines are shorter; the marginal cephalic spines are larger, shorter, and blunter; the thoracic segments, particularly the posteriormost segments, have shorter pleural spines that are straight or very slightly curved backward and not flared outward distally; and there are slightly more pleural ribs and larger marginal spines on the pygidium.

Cyphaspides pankowskiorum n. sp. differs from Cyphaspides ammari $\mathrm{n}$. sp. as follows: in C. pankowskiorum the genal spines are longer; the L1 lobes are slightly more distinct; the cephalic borders are less horizontal; the genal fields are not quite as swollen; the fine tubercles of the sculpture are coarser and not organized into radial caeca on the genal field; the tubercles of the sculpture are less bimodal; the eye is less stalked; the eye ridge is not as distinguishable on the genal field; the eyes are not as far apart or as posteriorly situated on the cephalon; the cephalic marginal spines are shorter and blunter; the pleural spine on the 13th thoracic segment extends well posterior to the pygidium (not opposite the posterior margin of the pygidium); there are fewer marginal spines along the anterolateral margins of the pygidium, opposite the first anterior pleural rib; and there are probably fewer axial rings in the pygidial axis.

Lawrence and Stammers (2014) illustrated an articulated carapace of this species from the "Devonian, Emsian, Timrhanrhart Formation, Struveaspis horizon, Jofre, Morocco." If this specimen is from Jorf, it is probably Eifelian in age and is a topotype of the newly described species. The Middle Devonian phacopid trilobite Struveaspis certainly occurs with this species at the Jorf locality.

Cyphaspides pankowskiorum n. sp. differs from Cyphaspides malbertii Basse and Müller, 2016 in the following characteristics: C. pankowskiorum has longer and stouter genal spines; it has a coarser sculpture of tubercles on the cephalon; it has small but distinct L1 lobes; it has a relatively wider (tr.) glabella; the posteriormost thoracic pleural spines are longer (extending well posterior to the pygidium) and stouter; and it has one fewer pair of pleural ribs and coarse marginal spines on the pygidium. C. pankowskiorum is quite similar to $C$. weugi Basse and Müller, 2016, but differs from the latter species in the following characteristics: the genal spines are longer and stouter, and they project posterolaterally from a position farther anterior on the cephalon; the posteriormost thoracic pleural spines project slightly posterolaterally, rather than posteromedially; and the posterior region of the thorax does not appear to be as strongly convergent posteriorly.

\section{Acknowledgments}

We thank H. Ait H'Ssaine for taking us to the localities in southeastern Morocco where these specimens were collected (Hamar Laghdad, Jorf and Talawarite); H. Ait H'Ssaine and his brother A. Ait H'Ssaine for preparing specimens that we have used in the present work and for their hospitality whenever we have visited Morocco; members of the Segaoui family of Erfoud (particularly Hamid and Hammad) for their help and advice when we visited Erfoud or their home at Hasselbied; and the government of Morocco for permission to work in Morocco. Part of this research was funded by a grant from the Natural Sciences and Engineering Research Council of Canada Discovery Grant (A7949) to BDEC.

\section{References}

Adrain, J.M., and Chatterton, B.D.E., 1994, The aulacopleurid trilobite Otarion, with new species from the Silurian of northwestern Canada: Journal of Paleontology, v. 68, p. 305-323.

Alberti, G.K.B., 1964, Neue Trilobiten aus dem marokkanischen und deutschen Unter- und Mitteldevon: Senckenbergiana lethaea, v. 45, p. $115-133$.

Alberti, G.K.B., 1966, Note préliminaire sur quelques trilobites (en particulier de Proétides) du Silurien, du Dévonien inférieur et du Dévonien moyen du Maroc: Notes du Service Géologique de Maroc, v. 26, p. 55-69.

Alberti, G.K.B., 1967, Neue obersilurische sowie unter- und mitteldevonische Trilobiten aus Marokko, Deutschland und einigen anderen europäischen Gebieten. I and II: Senckenbergiana lethaea, v. 48, p. 463-479, 481-509.

Alberti, G.K.B., 1969, Trilobiten des jüngeren Siluriums sowie des Unter- und Mitteldevons. I. Mit beitragen zur Silur-Devon-Stratigraphie einiger Gabiete Marokkos und Oberfrankens: Abhandlundgen der Senckenbergischen Naturforschenden Gesselschaft, v. 510, p. 1-692.

Alberti, G.K.B., 1970, Trilobiten des jüngeren Siluriums sowie des Unter- und Mitteldevons. II: Abhandlundgen der Senckenbergischen Naturforschenden Gesselschaft, v. 525, p. 1-233.

Alberti, G.K.B., 1981, Trilobiten des jüngeren Siluriums sowie des Unter- und Mitteldevons. III: Mit Beitragen zur Silur-Devon-Biostratigraphie (insbesondere nach Nowakiidae) in N-Afrika, Sardinien, Oberfranken, und im Harz: Senckenbergiana lethaea, v. 62, p. 1-75.

Alberti, G.K.B., 1982, Der Hamar Laghdad (Tafilalt, SE-Marokko) eine bedeutende Fundstätte devonischer Trilobiten: Natur und Museum, v. 112, p. $172-182$.

Alberti, G.K.B., 1983, Trilobiten des jüngeren Siluriums sowie des Unter- und Mitteldevons. IV: Senckenbergiana lethaea, v. 64, p. 1-88.

Angelin, N.P., 1854, Palaeontologia Scandanavica. I. Crustacea Formationis transitionis: Fascicule 2, I-IX, p. 21-92.

Barrande, J., 1846, Notice préliminaire sur le systême Silurien et les Trilobites de Bohême: Liepzig, Hirschfield, p. 1-97.

Barrande, J., 1852, Système Silurien du centre de la Bohéme. Ière Partie. Recherches paléontologiques. Volume 1: Crustacés: Trilobites: Prague and Paris, Barrande, p. 1-935 (+ 49 plates).

Barrande, J., 1872, Système Silurien du centre de la Bohéme. Ière Partie: Recherches Paléontologiques. - Supplément au Vol. 1. Trilobites, Crustacés divers et Poissons. Texte Troisième partie. Crustacés divers, non trilobitiques: Prague, Barrande, p. 434-619, pls. 1-35.

Basse, M., 1997, Trilobiten aus mittlerem Devon des Rhenohercynikums: II. Proetida (2), Ptychopariida, Phacopida (1): Palaeontographica, Abteilung A, v. 246, p. 53-142.

Basse, M., and Lemke, U., 1996, Trilobiten aus mittlerem Givetium (MittelDevon) des nördlichen Rechtsrheinischen Schiefergebirges: Geologie und Paläontologie in Westfalen, v. 46, 65 p.

Basse, M., and Müller, P., 2016, Trilobiten aus dem Ober-Emsium und frühen Eifelium der südlichen Lahnmulde (Rupbach-Schiefer, Leun-Schiefer und Ballersbach-Kalk): Senckenberg Forschungsinstitut und Naturmuseum Frankfurt, v. 572, p. 1-329.

Becker, R.T., and House, M.R., 1994, International Devonian goniatite zonation, Emsian to Givetian, with new records from Morocco: Senckenberg Forschungsinstitut Senckenberg, v. 169, p. 79-135.

Bensaid, M., Bultynck, P., Sartenaer, P., Walliser, O.H., and Ziegler, W., 1985, The Givetian-Frasnian boundary in pre-Sahara Morocco: Courier Fosrschungsinstitut Senckenberg, v. 75, p. 287-300.

Brett, C.E., Zambito, J.J., Hunda, B.R., and Schindler, E., 2012, Mid-Paleozoic trilobite Lagerstätten: Models of diagenetically enhanced obrution deposits: Palaois, v. 27, p. 326-345.

Bultynck, P., and Hollard, H., 1980, Distribution comparée de Conodontes et Goniatites dévoniens de plaines du Dra, de Ma'der et du Tafilalt (Maroc): Leuven University Press, v. 1, 73 p.

Bultynck, P., and Jacobs, L., 1981, Conodontes et sédimentologie des couches de passage du Givetien au Frasnien dans le Nord du Tafilalt et dans le Ma'der (Maroc Présaharien): Bulletin Institut Royal des Sciences Naturelles de Belgique, v. 53, p. 1-23.

Bultynck, P., and Walliser, O.H., 2000, Devonian boundaries of the Moroccan Anti-Atlas: Courier Forschungsinstitut Senckenberg, v. 225, p. 211-226.

Chatterton, B.D.E., and Gibb, S., 2010, Latest Early to Middle Devonian trilobites from the Erbenochile Bed, Jbel Issoumour, southeastern Morocco: Journal of Paleontology, v. 84, p. 1188-1205. 
Chatterton, B.D.E., Fortey, R.A., Brett, K., Gibb, S., and McKellar, R., 2006, Trilobites from the upper Lower to lower Middle Devonian Timrhanrhart Formation, Jbel Gara el Zguilma, southern Morocco: Palaeontographica Canadiana, v. 25, 177 p.

Copper, P., 2002, Silurian and Devonian reefs: 80 million years of greenhouse between two ice ages. Phanerozoic reef patterns: Society of Economic Paleontologists and Mineralogists, Special Publication, v. 72, p. 181-238.

Corbacho, J., and López-Soriano, F.J., 2013, Two new species of Trochurine trilobites from the Middle Devonian (Eifelian) of southern Morocco: Battaleria, v. 18, p. 15-24.

Crônier, C., Oudot, M., Klug, C., and De Baets, K., 2018, Trilobites from the Red Fauna (latest Emsian) of Hamar Laghdad, Morocco and their biodiversity: Neues Jahrbuch für Geologie und Paläontologue Abhandlungen, v. 290, 241-276.

Fortey, R.A., and Owens, R.M., 1975, Proetida-a new order of trilobites: Fossils and Strata, v. 4, p. 227-239.

Gibb, S., and Chatterton, B.D.E., 2010, Gerastos (Order Proetida; Class Trilobita) from the Lower to Middle Devonian of the southern Moroccan AntiAtlas region: Palaeontographica Canadiana, no. 30, 89 p.

Gluchowski, E., and Racki, G., 2005, Disarticulated crinoid stems from the Devonian and Carboniferous of North Devon, England: Proceedings of the Yorkshire Geological Society, v. 55, p. 161-172.

Golonka, J., 2002, Plate-tectonic maps of the Phanerozoic: Society of Economic Paleontologists and Mineralogists Special Publication 72, p. 21-75.

Golonka, J., Ross, M.I., and Scotese, C.R., 1994, Phanerozoic paleogeographic and paleoclimatic modeling maps. Pangaea: Global environments and resources: Canadian Society of Petroleum Geologists Memoir, v. 17, p. $1-47$.

Helling, S., and Schöllmann, L., 2018, Trilobiten aus dem Grenzbereich Emsium/Eifelium (Devon) im Raum Winterberg/Züschen (österliches Sauerland): Geologie und Palaeontologie in Westfalen, v. 90, p. 25-65.

Hollard, H., 1981, Principaux caractères des formations dévoniens de l'Anti Atlas: Notes du Service Géologique de Maroc, v. 42, p. 15-22.

Horný, R., and Bastl, F., 1970, Type specimens of fossils in the National Museum Prague. Volume 1. Trilobita: Prague, Museum of Natural History, p. 1-354.

Jell, P.A., and Adrain, J.M., 2003, Available generic names for trilobites: Memoirs of the Queensland Museum, v. 48, p. 331-553.

Kim, A.I., Ëlkin, E.A., Erina, M.V., and Gratsianova, R.T., 1978a, Type sections of the Lower and Middle Devonian boundary beds in middle Asia A guide to field excursions, in Sokolov, B.S., and V.G. Garkoveta, eds. Field Session of the International Subcommission on Devonian Stratigraphy, Samarkand, USSR, 1978: Tashkent Ministry of Geology of the USSR, 54 p. [in Russian and English]

Kim, A.I., Ëlkin, E.A., Erina, M.V., and Gratsianova, R.T., 1978b, Atlas of the paleontological plates. Supplement to a guide of the Field Excursions: Field Session of the International Subcommission on Devonian Stratigraphy, Samarkand, USSR, 1978: Tashkent Ministry of Geology of the USSR, p. 1-48, pls 1-78. [in Russian]

Klug, C., Schulz, H., and De Baets, K., 2009, Red Devonian trilobites with green eyes from Morocco and the silicification of the trilobite exoskeleton: Acta Palaeontologica Polonica, v. 54, p. 117-123.
Lawrence, P., and Stammers, S., 2014, Trilobites of the World. An Atlas of 1000 Photographs: Manchester, Siri Scientific Press, 416 p.

Luo, H., and Jiang, N., 1985, Devonian trilobites from southeastern Yunnan: Acta Palaeontologica Sinica, v. 24, p. 369-376. [in Chinese with English abstract]

McKellar, R.C., and Chatterton, B.D.E., 2009, Early and Middle Devonian Phacopidae (Trilobita) of southern Morocco: Palaeontographica Canadiana, v. 28,110 p.

Moore, R.C., ed., 1959, Treatise on Invertebrate Paleontology, Part O, Arthropoda 1: Boulder, Colorado, and Lawrence, Kansas, Geological Society of America and University of Kansas Press, 560 p.

Novák, O., 1890, Vergleichende Studien an einigen Trilobiten aus dem Hercyn von Bicken, Wildungen, Greifenstein und Böhmen: Paläontologische Abhandlungen, v. 1, p. 1-46.

Owens, R.M., Ivanova, O., Kim, I., Popov, L.E., and Feist, R., 2010, Lower and Middle Devonian trilobites from southern Uzbekistan: Memoirs of the Association of Australasian Palaeontologists, v. 39, p. 211-244.

Pillet, J., 1972, Les trilobites du Dévonien inférieur et du Dévonien moyen du sud-est du Massif armoricain: Societé D’Études scientifiques de l'Anjou, Mémoire 1, $307 \mathrm{p}$.

Prantl, F., and Prribyl, A., 1950, A revision of the Bohemian representatives of the family Otarionidae R. and E. Richter (Trilobitae): Sborník Státního Geologického Ústava Ćeskslovenske Republiky, v. 17, p. 353-512.

Pribyl, A., 1947, Aulacopleura and the Otarionidae: Journal of Paleontology, v. 21 , p. $537-545$.

Přibyl, A.,1949, O několika nových nebo málo známých trilobitech z českého devonu: Vestník Státního Geologického Ústava Ceskslovenske Republiky, v. 24, p. 293-311.

Přibyl, A., and Vaněk, J., 1977, Einige neue taxa der Trilobiten aus dem Mittelböhmischen Silur und Devon: časopis Národniho Muzea, oddil Př́rodovědný, v. 144, p. 83-88.

Richter, R., and Richter, E., 1943, Studien im Paläozoikum der MittlemeerLänder. 4a. Trilobiten aus dem Devon von Marokko, mit einem Anhang über Arten des Rheinlands: Senckenbergiana, v. 26, p. 116-199.

Roemer, F.A. 1855, Beiträge zur geoligischen Kenntniss des nordwestlichen Harzgebirges, dritte abtheilung: Palaeontographica, v. 5, 40 p.

Růžička, R., 1939, Noví trilobiti z Barrandienu: Rozpravy II, třídy českě Akademie, v. 48 , p. $1-8$ (+ 1 plate $)$.

Vogdes, A.W., 1925, Palaeozoic Crustacea: Transactions of the San Diego Society of Natural History, v. 4, p. 1-154, pls. 1, 2

Walch, J.E.I., 1771, Die Naturgeschichte der Versteinerungen, Dritter Theil: Nuremberg, Paul Jonathan Felstecker, 235 p. [the trilobite chapter is p. 120-147, 211-215, 221-223, pl. 9a-c, e, f; p. 121-144 mispaginated 171-194; microfacsimile published 1970 in Landmarks of Science]

Yi, Y-E, and Hsiang, L-W., 1975, Middle Devonian trilobites of Nantan, Kwangsi: Collections of Articles on Strata and Fossils, 1: Professional Papers of Stratigraphy and Palaeontology Peking Fossils, v. 1, p. 105 110. [Zoological Record v. 114]

Accepted: 14 August 2019 